\title{
Brain metastases from hepatocellular carcinoma: recent advances and future avenues
}

\author{
Shanshan Wang ${ }^{1, *}$, Anqiang Wang ${ }^{1, *}$, Jianzhen Lin $^{1, *}$, Yuan Xie ${ }^{1}$, Liangcai Wu ${ }^{1}$, \\ Hanchun Huang ${ }^{1}$, Jin Bian ${ }^{1}$, Xiaobo Yang${ }^{1}$, Xueshuai Wan ${ }^{1}$, Haitao Zhao ${ }^{1,2}$ and \\ Jiefu Huang ${ }^{1}$ \\ ${ }^{1}$ Department of Liver Surgery, Peking Union Medical College Hospital, Chinese Academy of Medical Sciences and Peking \\ Union Medical College, Beijing, China \\ ${ }^{2}$ Center of Translational Medicine, Peking Union Medical College Hospital, Chinese Academy of Medical Sciences and Peking \\ Union Medical College, Beijing, China \\ * These authors have contributed equally to this work \\ Correspondence to: Haitao Zhao, email: zhaoht@pumch.cn
}

Jiefu Huang, email: pumchzht@aliyun.com

Keywords: brain metastases, hepatocellular carcinoma, radiotherapy, targeted therapy, immunotherapy

Received: November 21,2016 Accepted: February 07,2017 Published: February 25, 2017

Copyright: Wang et al. This is an open-access article distributed under the terms of the Creative Commons Attribution License (CC-BY), which permits unrestricted use, distribution, and reproduction in any medium, provided the original author and source are credited.

\section{ABSTRACT}

The incidence of brain metastases from hepatocellular carcinoma (BMHCC) is becoming more frequent than that of the past as a result of prolonged survival of patients with HCC. Compared with brain metastases from other types of cancer, BMHCC tends to exhibit a high incidence of intracerebral hemorrhage (ICH) and poor liver function. Unfortunately, the prognosis is extremely poor for patients with BMHCC owing to the limited treatment selection. Currently, optimal treatment requires multidisciplinary approaches including surgery, whole-brain radiation therapy and stereotactic radiosurgery. Besides these traditional approaches, novel treatments such as target therapy and immunotherapy provide an opportunity to improve the survival of these patients. This review provides an overview of the incidence, characteristics, prognosis, and current and potential future management strategies for BMHCC.

\section{INTRODUCTION}

Brain metastases from hepatocellular carcinoma (BMHCC) are extremely rare, occurring in approximately $1 \%$ of HCC patients [1]. Previously, clinicians paid little attention to this clinical scenario because symptoms suggestive of metastasis were rarely observed due to the poor overall prognosis of HCC patients [2]. However, as a result of recent progress in both the diagnosis and treatment of $\mathrm{HCC}$, prognosis $\mathrm{HCC}$ have improved much, brain metastases from HCC (BMHCC) are now being diagnosed more frequently $[3,4]$. Disappointingly, the outcome of BMHCC has not substantially changed despite advances in therapeutic options for BM and HCC. The substantial burden of morbidity and mortality associated with these metastases has motivated research and technological innovation over the past two decades. The purpose of this review is to highlight emerging data on BMHCC epidemiology and modalities used in the management of BMHCC, briefly outline current treatment approaches with an emphasis on novel and emerging therapies, and discuss areas of future research focus.

\section{INCIDENCE OF BRAIN METASTASES IN HCC PATIENTS}

Brain metastases (BM) are the most common and devastating neurologic complications of systemic cancer and occur in $20 \%$ to $40 \%$ of advanced-stage cancers $[5,6]$. BM mainly occurs in patients with lung cancer (40-50\%), breast cancer (15-25\%), and melanoma (5-20\%) [7-9] and $\mathrm{BM}$ arising from $\mathrm{HCC}$ is extremely rare, with a reported incidence ranging from $0.2 \%$ to $2.2 \%$ [10-15]. As stated by Jiang et al. [3], these figures probably underestimate the scale of the problem, and several autopsy series suggest that the underlying incidence is probably around $2.0-7.7 \%$ [13]. Nevertheless, the incidence of BMHCC is much lower than that of HCC metastasis to other organs, which may be due to the low affinity of HCC for the central nervous system (CNS) and the rapid disease course and 
Table 1: Summary of selected reported case-series of BMHCC

\begin{tabular}{|c|c|c|c|c|c|c|c|c|c|c|c|c|c|c|c|}
\hline $\begin{array}{l}\text { Study } \\
\text { (year) }\end{array}$ & Country & \begin{tabular}{|l} 
Years \\
included
\end{tabular} & $\begin{array}{l}\text { HCC } \\
\text { cases }\end{array}$ & $\begin{array}{l}\text { Cases } \\
\text { (n) }\end{array}$ & $\begin{array}{l}\text { Inc } \\
(\%)\end{array}$ & $\begin{array}{l}\text { Male } \\
(\%)\end{array}$ & $\begin{array}{l}\text { Median } \\
\text { age } \\
\text { (years) }\end{array}$ & $\begin{array}{l}\text { Single } \\
\text { BM (\%) }\end{array}$ & $\begin{array}{l}\text { ICH } \\
(\%)\end{array}$ & $\begin{array}{l}\text { Diagnosis } \\
\text { tool }\end{array}$ & $\begin{array}{l}\text { Time } \\
\text { since } \\
\text { HCC } \\
\text { diagnosis } \\
\text { (months) }\end{array}$ & ECM (\%) & $\begin{array}{l}\text { Treatment } \\
\text { modality }(\%)\end{array}$ & OS (months) & $\begin{array}{l}\text { Significant } \\
\text { prognostic } \\
\text { factors }\end{array}$ \\
\hline $\begin{array}{l}\text { Kim et } \\
\text { al.11(1998) }\end{array}$ & Korea & $1987-1991$ & 3100 & 7 & 0.23 & 85.7 & 56 & NA & 57.1 & $\begin{array}{l}\text { CT or/and } \\
\text { MRI }\end{array}$ & 15.3 & Lung:28.6 & RT & 3.9 & NA \\
\hline $\begin{array}{l}\text { Chang et } \\
\text { al.49(2004) }\end{array}$ & Taiwan & 1986-2002 & NA & 45 & NA & 88.9 & NA & 58 & 40 & $\begin{array}{l}\text { CT or/and } \\
\text { MRI }\end{array}$ & 10.5 & NA & SR and/or RT & $\mathrm{SR} / \mathrm{RT}:>4 \mathrm{SC}:<1$ & Single lesion \\
\hline $\begin{array}{l}\text { Natsuizak et } \\
\text { al.13(2005) }\end{array}$ & Japan & 1995-2001 & 482 & 5 & 1.04 & NA & 62 & NA & NA & NA & NA & NA & RT,SR & NA & NA \\
\hline $\begin{array}{l}\text { Seinfeld et } \\
\text { al.14 (2006) }\end{array}$ & USA & 1992-2004 & NA & 3 & NA & 57.8 & 33.3 & NA & NA & $\begin{array}{l}\text { CT or/and } \\
\text { MRI }\end{array}$ & NA & NA & $\mathrm{SR}+\mathrm{SRT} ; \mathrm{SR}$ & 2 & NA \\
\hline $\begin{array}{l}\text { Chen et } \\
\text { al.16 (2007) }\end{array}$ & Taiwan & 1993-2003 & 15,008 & 32 & 0.21 & NA & 32 & 90 & NA & $\begin{array}{l}\text { CT or/and } \\
\text { MRI }\end{array}$ & NA & NA & NA & 3.3 & NA \\
\hline $\begin{array}{l}\text { Hsieh et al. } \\
52(2009)\end{array}$ & Taiwan & NA & NA & 42 & NA & 81.0 & 56 & 67 & 43 & $\begin{array}{l}\text { CT or/and } \\
\text { MRI }\end{array}$ & 15.4 & $\begin{array}{l}\text { ALL: } 81.0 \\
\text { Lung: } 47.6 \\
\text { Bone: } 14.2 \\
\text { Lymph } \\
\text { nodes: } 19.0 \\
\text { others: } 14.2\end{array}$ & $\begin{array}{l}\text { SC/ } \\
\text { symptomatic } \\
\text { therapy:33.3 } \\
\text { WBRT:52.4 } \\
\text { SR+WBRT: } 9.6 \\
\text { SR: } 4.8\end{array}$ & $\begin{array}{c}\text { ALL:1.2 ICH:1.0 } \\
\text { no-ICH: } 1.3\end{array}$ & $\begin{array}{l}\text { ICH did not } \\
\text { influence }\end{array}$ \\
\hline $\begin{array}{l}\text { Chan et al. } \\
10(2009)\end{array}$ & Taiwan & $1988-2008$ & 2245 & 28 & 1.2 & NA & NA & 89 & NA & $\begin{array}{l}\text { CT or/and } \\
\text { MRI }\end{array}$ & NA & NA & SR:29.1 & 6.1 & NA \\
\hline $\begin{array}{l}\text { Choi et al.33 } \\
\text { (2009) }\end{array}$ & Korea & 1995-2006 & 6919 & 62 & 0.9 & 75.8 & 54 & 62.9 & 55 & $\begin{array}{l}\text { CT or/and } \\
\text { MRI }\end{array}$ & 18.2 & $\begin{array}{l}\text { ALL:80.6 } \\
\text { Lung :69.4 } \\
\text { Bone:25.8 } \\
\text { Lymph } \\
\text { node :8.1 } \\
\text { Omentum:4.8 } \\
\text { Adrenal:3.2 }\end{array}$ & $\begin{array}{l}\text { Steroids } \\
\text { alone:40.3 SR: } \\
9.7 \quad \text { WBRT } \\
\text { alone :25.8 } \\
\text { GKS:16.1 } \\
\text { SR+WBRT:8.1 }\end{array}$ & $\begin{array}{cr}\text { ALL:1.7 } & \text { SC:0.5 } \\
\text { Resection } & \text { or } \\
\text { WBRT or GKS:2.5 } \\
\text { SR+WBRT:8.4 }\end{array}$ & $\begin{array}{l}\text { Single lesion, } \\
\text { Child-Pugh's } \\
\text { classification } \\
\text { A Any } \\
\text { treatment } \\
\text { modalities for } \\
\text { BM }\end{array}$ \\
\hline $\begin{array}{l}\text { Han et al.21 } \\
(2010)\end{array}$ & Korea & 1991-2007 & NA & 20 & 0.05 & 85 & 55 & 50 & 91 & $\begin{array}{l}\text { CT or/and } \\
\text { MRI }\end{array}$ & 18.5 & 85 & $\begin{array}{l}\text { GKS/WBRT/ } \\
\text { SRT:90 SC:10 }\end{array}$ & $\begin{array}{ll}\text { ALL:2 } & \text { WBRT } \\
\text { and/or } & \text { GKS:4 } \\
\text { SR+adjuvant } & \\
\text { therapy:2 }\end{array}$ & $\begin{array}{l}\text { No } r \text { ECMs, } \\
\text { age }<60 \\
\text { years, } \quad \text { no } \\
\text { recurrent ICH }\end{array}$ \\
\hline $\begin{array}{l}\text { Uchino et al. } \\
51(2011)\end{array}$ & Japan & $1990-2006$ & 2386 & 4 & 0.17 & NA & NA & NA & NA & NA & NA & NA & $\begin{array}{l}\text { Radiation:50; } \\
\text { No } \\
\text { Treatment:50 }\end{array}$ & NA & NA \\
\hline $\begin{array}{l}\text { Hsiao et } \\
\text { al.17 (2011) }\end{array}$ & Taiwan & 1993-2006 & NA & 36 & NA & 80.5 & 56 & NA & NA & $\begin{array}{l}\text { CT or/and } \\
\text { MRI }\end{array}$ & 11.5 & $\begin{array}{c}\text { Lung: } 33.3 \\
\text { Bone: } 25\end{array}$ & NA & 1 & NA \\
\hline $\begin{array}{l}\text { Jiang et al.3 } \\
(2012)\end{array}$ & China & 1994-2009 & 8676 & 41 & 0.47 & 80.5 & 48.5 & 58.5 & 46.3 & $\begin{array}{l}\mathrm{CT} / \mathrm{MRI} / \\
\text { PET-CT }\end{array}$ & 15 & $\begin{array}{l}80.5 \text { Lung: } \\
75.6 \text { Bone: } 22 \\
\text { Adrenal :9.8 } \\
\text { other sites: } 7.3\end{array}$ & \begin{tabular}{l} 
SR or WBRT \\
or and/or \\
SRS: 42.5 \\
Steroid \\
\multicolumn{2}{c}{ only: 57.5}
\end{tabular} & $\begin{array}{l}\text { ALL:3 SR/WBRT/ } \\
\text { GKS:6.8 SC:2.7 }\end{array}$ & 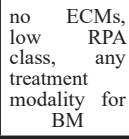 \\
\hline $\begin{array}{l}\text { Han et al. } 86 \\
\text { (2013) }\end{array}$ & Korea & 1998-2011 & NA & 32 & NA & 87.5 & 54 & 40.6 & 76.3 & $\begin{array}{l}\mathrm{CT} \text { or/and } \\
\text { MRI }\end{array}$ & 26 & $\begin{array}{l}96.9 \\
\text { Lung:87.5 } \\
\text { Lymph } \\
\text { node:31.3 }\end{array}$ & SRS & 2.8 & $\underset{\text { BM,AFP }}{\text { Volume of }}$ \\
\hline $\begin{array}{l}\text { Han et al.2 } \\
(2013)\end{array}$ & Korea & 2001-2012 & 5015 & 33 & 0.65 & 90.9 & 62 & 52 & 52 & $\begin{array}{l}\text { CT or/and } \\
\text { MRI }\end{array}$ & 18.3 & \begin{tabular}{l}
94 Lung :73 \\
Bone: 18 \\
Lymph \\
node: 24 \\
Adrenal:6 \\
\multicolumn{1}{c}{ Skin:3 }
\end{tabular} & $\begin{array}{lcc}\text { SR } & : 12 \quad \text { SR } \\
+ & \text { WBRT:18 } \\
\text { GKS: } & 33 \text { GKS } \\
+ & \text { WBRT: } 6 \\
+ & \text { WBRT: } \quad 12 \\
\text { Palliative }: 18\end{array}$ & $\begin{array}{l}2.6 \quad \text { SR/ } \\
\text { SR+WBRT:6.3; } \\
\text { GKS/WBRT/ } \\
\text { GKS+WBRT: } 2.6 \\
\quad \text { steroid: } 0.25\end{array}$ & $\begin{array}{l}\text { SR, no ICH, } \\
\text { Child-Pugh's } \\
\text { classification } \\
\text { A }\end{array}$ \\
\hline $\begin{array}{l}\text { Park et al.34 } \\
\text { (2013) }\end{array}$ & Korea & 2004-2012 & NA & 59 & NA & 83 & 52.2 & NA & 33.9 & $\begin{array}{l}\text { CT and } \\
\text { MRI }\end{array}$ & NA & 93.2 & $\begin{array}{l}\text { SC: } 28.8 \\
\text { GKS: } 33.9 \\
\text { SR: } 23.7 \\
\text { WBRT: } 13.6\end{array}$ & $\begin{array}{cr}\text { ALL:1.1 } & \text { SC:0.5 } \\
\text { GKS:1.3 } & \text { SR:3.7 } \\
\text { WBRT: } 1.1\end{array}$ & $\begin{array}{l}\text { Active } \\
\text { intervention } \\
\text { for BM, } \\
\text { RPA class, } \\
\text { Child-Pugh's } \\
\text { classification } \\
\end{array}$ \\
\hline $\begin{array}{l}\text { Park et al.36 } \\
\text { (2014) }\end{array}$ & Korea & 1993-2012 & NA & 73 & NA & 87.7 & 52.5 & 56.2 & 47.9 & $\begin{array}{l}\text { MRI and/ } \\
\text { or CT }\end{array}$ & NA & $\begin{array}{l}\text { ALL:93.2 } \\
\text { lung :49.3 } \\
\text { Bone:6.8 } \\
\text { Lymph } \\
\text { node :2.8 } \\
\text { Multiple:34.3 }\end{array}$ & GKS & 4 & $\begin{array}{l}\text { age of } \leq 65 \\
\text { years, Child- } \\
\text { Pugh Class } \\
\text { A, KPS } \geq 70 \text {, } \\
\text { and low RPA } \\
\text { class (I or II) }\end{array}$ \\
\hline $\begin{array}{l}\text { Lim et al. } 12 \\
\text { (2014) }\end{array}$ & Korea & $1995-2011$ & 10,615 & 118 & 1.1 & 81.4 & 54 & 54.2 & 55.1 & $\begin{array}{l}\text { CT or/and } \\
\text { MRI }\end{array}$ & NA & $\begin{array}{l}\text { ALL:95 } \\
\text { Lung:72.9 } \\
\text { Bone : }: 23.7 \\
\text { Lymph } \\
\text { node: } 11.9 \\
\text { Omentum:3.4 } \\
\text { Adrenal gland } \\
\quad: 5.9\end{array}$ & $\begin{array}{l}\text { Active } \\
\text { treatment: } \\
\text { SC:41 }\end{array}$ & $\begin{array}{l}\text { ALL: } 1.5 \quad \text { Active } \\
\text { treatment:2.6 SC:0.5 }\end{array}$ & $\begin{array}{l}\text { Number of } \\
\text { BM, Child- } \\
\text { Pugh-Class } \\
\text { score, AFP } \\
\quad \text { level }\end{array}$ \\
\hline $\begin{array}{l}\text { Kim et al.35 } \\
(2014)\end{array}$ & Korea & $2000-2011$ & NA & 95 & NA & 86.4 & 56.1 & 44.2 & 74.7 & $\begin{array}{l}\text { CT or/and } \\
\text { MRI }\end{array}$ & 29.5 & $\begin{array}{l}92.6 \\
\text { Lung: } 88.4 \\
\text { Lymph } \\
\text { node :33.7 } \\
\text { Bone: } 14.7 \\
\text { Adrenal: } 9.5 \\
\text { Others:6.3 }\end{array}$ & 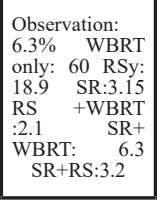 & $\begin{array}{lr}\text { ALL:3 } & \text { Single } \\
\text { or none: } & 2.61 \\
\text { Multimodality: } 10.56\end{array}$ & $\begin{array}{l}\text { Age, ECOG } \\
\text { PS, Child- } \\
\text { Pugh class, } \\
\text { AFP level, } \\
\text { controlled } \\
\text { primary } \\
\text { tumor status } \\
\text { number of } \\
\text { BM }\end{array}$ \\
\hline
\end{tabular}




\begin{tabular}{|c|c|c|c|c|c|c|c|c|c|c|c|c|c|c|c|}
\hline $\begin{array}{l}\text { Xu et al.4 } \\
(2014)\end{array}$ & China & 2011-2013 & NA & 14 & NA & 85.7 & 53 & 57.1 & 59.1 & NA & 26 & $\begin{array}{l}\text { Lung: } 57.1 \\
\text { Bone: } 35.7 \\
\text { Both: } 21.4\end{array}$ & GKS & 5 & $\begin{array}{l}\text { Total volume } \\
\text { of BM, RPA } \\
\text { class and AFP } \\
\text { level }\end{array}$ \\
\hline $\begin{array}{l}\text { Kim et al.50 } \\
(2015)\end{array}$ & Korea & $2000-2013$ & NA & 105 & NA & 84 & 56.3 & 45.7 & 79 & $\begin{array}{l}\text { CT or/and } \\
\text { MRI }\end{array}$ & 29.5 & $\begin{array}{l}93.8 \\
\text { Lung:91.4 } \\
\text { Lymph } \\
\text { node :28.4 } \\
\text { Bone:11.1 } \\
\text { Adrenal: } 8.6 \\
\text { Others:6.2 }\end{array}$ & $\begin{array}{lr}\text { WBRT } & \text { only: } \\
58.0 & \text { SR+ } \\
\text { WBRT: } & 8.6 \text { RS } \\
\text { +WBRT }: 3.7 \\
\text { SR:3.7 RS:22.2 } \\
\text { SR+RS:3.7 }\end{array}$ & $\begin{array}{lr}\text { ALL:3 } & \text { Single } \\
\text { or none: } & 2.61 \\
\text { Multimodality: } 10.56\end{array}$ & $\begin{array}{l}\text { Age, ECOG } \\
\text { PS, Child- } \\
\text { Pugh class, } \\
\text { AFP level, } \\
\text { controlled } \\
\text { primary } \\
\text { tumor status } \\
\text {,number of } \\
\text { BM }\end{array}$ \\
\hline $\begin{array}{l}\text { Park et } \\
\text { al.53(2015) }\end{array}$ & Korea & $2000-2013$ & & 97 & NA & 85.57 & 56.6 & 37.1 & 69.1 & $\begin{array}{l}\text { CT or/and } \\
\text { MRI }\end{array}$ & NA & $\begin{array}{l}95.9 \\
\text { Lung:94.8 } \\
\text { Lymph } \\
\text { node :27.8 } \\
\text { Bone: } 17.5 \\
\text { Adrenal: } 9.3 \\
\text { Others: } 14.4\end{array}$ & $\begin{array}{l}\text { WBRT: } \quad 73.2 \\
\text { surgery/ } \\
\text { radiosurgery + } \\
\text { WBRT: } 18.6 \\
\text { WBRT as } \\
\text { salvage }: 8.2\end{array}$ & $\begin{array}{c}\text { ALL:3.5 WBRT:1.1 } \\
\text { GKS: } 1.3 \text { SR:3.7 } \\
\text { SC: } 0.5\end{array}$ & $\begin{array}{l}\text { ECOG PS, } \\
\text { Child-Pugh } \\
\text { classification, } \\
\text { AFP level, } \\
\text { treatment aim }\end{array}$ \\
\hline $\begin{array}{l}\text { Yamakawa } \\
\text { et al.31 } \\
(2015)\end{array}$ & Japan & 2004-2012 & 1702 & 15 & 0.9 & 66.67 & 64 & NA & 66.7 & $\begin{array}{l}\text { CT or/and } \\
\text { MRI }\end{array}$ & 17.8 & Lung:73.3 & $\begin{array}{l}\text { WBRT: } 66.7 \\
\text { GKS: } 33.3 \\
\text { SRT:26.7 }\end{array}$ & RT:5 SC: 0.6 & ICH,RT \\
\hline $\begin{array}{l}\text { Kato et } \\
\text { al.105 } \\
(2015)\end{array}$ & Japan & 2011-2015 & NA & 7 & 10.8 & NA & NA & NA & NA & NA & NA & NA & Cyber-knife & NA & NA \\
\hline
\end{tabular}

Abbreviations: BMHCC: Brain metastases from hepatocellular carcinoma , Inc: Incidence of brain metastases, ECM: Percentage of patients diagnosed with extra-cranial metastases, OS: Overall survival, ECOG: Eastern Cooperative Oncology Group, PS: Performance status, KPS: Karnofsky performance status, ICH: Incidence of intracranial hemorrhage, SR: Surgical resection, SC: Supportive care; RT: Radiotherapy, SRT: Stereotactic radiotherapy, SRS: Stereotactic radiosurgery, WBRT: whole brain radiotherapy, GKS: Gamma knife surgery, RPA: Recursive Partitioning Analysis, NA: Not available

Table 2: Comparison of the clinical characteristics of brain metastases from different tumors

\begin{tabular}{|l|c|c|c|c|c|c|}
\hline Primary tumor & Pro (\%) & Inc (\%) & Single BM (\%) & ECM (\%) & $\begin{array}{l}\text { Time since primary cancer } \\
\text { diagnosis (months) }\end{array}$ & OS (months) \\
\hline Lung cancer & $40-50^{8,9}$ & $30-50^{23,39,57,60}$ & $42-45^{37,40,45}$ & $15-69^{23,38-40}$ & $24-33^{23,24}$ & $3-7^{57,58,60}$ \\
\hline Breast cancer & $15-25^{8,9}$ & $10-30^{26,46}$ & $20-43^{41,42,46}$ & $14-83^{27,41,42}$ & $32-39^{25-27}$ & $2-16^{26,42,55}$ \\
\hline Melanoma & $5-20^{8,9}$ & $17-45^{43,60}$ & $13-29^{28,43,47,48}$ & $45-66^{37,43}$ & $24-48^{28,29}$ & $3-6^{59-61}$ \\
\hline HCC & NA & $0.2-2.2^{10-15}$ & $37.1-90.0^{16,53}$ & $80.5-96.9^{3,86}$ & $10.5-29.5^{35,49}$ & $1-3^{17,50,86}$ \\
\hline
\end{tabular}

Abbreviations: HCC: Hepatocellular carcinoma, Pro: Proportion of brain metastases from a specific tumor, Inc: Number of patients of brain metastases from a specific tumor/ Number of the specific tumor patients, ECM: Percentage of patients diagnosed with extra-cranial metastases, OS: Overall survival, NA: Not available

short survival time of patients with HCC, which decreases the likelihood brain metastases $[16,17]$. However, the incidence appears to have increased over past decades (Table 1). The first large retrospective study published in 1998 by Kim et al. found that only seven of 3,100 HCC patients had intracranial metastases [11]. On the basis of data from 10,615 patients recorded in the Yonsei University Health System between 1973 and 2001, Lim et al. suggested that the incidence had increased to $1.1 \%$ [12]. Similarly, Shao et al. assessed 158 patients with advanced HCC who were treated with antiangiogenic targeted therapy at National Taiwan University Hospital between 2005 and 2009, and reported an increase in incidence to $7 \%$ [18]. This progressive increase is probably due to longer survival of patients with HCC [7] and increased utilization of sensitive detection methods, particularly MRI, which is currently used to assess approximately $64 \%$ of patients with cancer compared with only $2 \%$ of similar patients groups 20 years ago [19, 20]. Given these data, $\mathrm{BM}$ can no longer be regarded as a rare event in $\mathrm{HCC}$ patients.

\section{CHARACTERISTICS OF BMHCC PATIENTS}

\section{Formation and timing of brain metastases}

Brain metastases tend to occur in patients with advanced HCC and distant metastasis is a multistep process, often referred to as metastatic cascade (Figure 1) $[21,22]$. As shown in Table 1, the interval from initial HCC diagnosis to discovery of brain metastasis was between 10.5 and 29.5 months. Importantly, most of the published series reported an interval $<20$ months, which is shorter than that patients with brain metastases from lung cancer, breast cancer and melanoma (Table 2) [23-29] .

\section{Metastatic disease}

BMHCC patients generally have advanced liver disease and a high percentage of synchronous extra- 
Table 3: Prognostic scores used for patients with brain metastases

\begin{tabular}{|c|c|c|c|c|c|c|c|c|c|}
\hline Score & Age (years) & Performance status & $\begin{array}{l}\text { Number } \\
\text { of brain } \\
\text { metastases }\end{array}$ & $\begin{array}{l}\text { Extra-cranial } \\
\text { metastases }\end{array}$ & $\begin{array}{l}\text { Controlled } \\
\text { Primary }\end{array}$ & Class I & Class II & Class III & $\begin{array}{l}\text { Class } \\
\text { IV }\end{array}$ \\
\hline $\begin{array}{l}\text { RPA Derived from } 3 \\
\text { prospective RTOG } \\
\text { studies, } n=1,200\end{array}$ & age $<65$ & $\mathrm{KPS} \geq 70 \mathrm{vs}<70$ & NA & Present or Absent & Yes or No & $\begin{array}{l}\text { All } 4 \\
\text { factors } \\
\text { favorable } \\
(7.1 \text { mos })\end{array}$ & $\begin{array}{l}\text { other } \\
\text { patients }\end{array}$ & $\begin{array}{l}\text { KPS }<70 \\
(2.3 \text { mos })\end{array}$ & NA \\
\hline $\begin{array}{l}\text { GPA Derived from } \\
5 \text { prospective RTOG } \\
\text { studies, } \mathrm{n}=1,960\end{array}$ & $\begin{array}{|lr|}<50: 1 & \text { Point } \\
50-60: & 0.5 \\
\text { points } & >60: \\
0 \text { points }\end{array}$ & $\begin{array}{l}\text { KPS 90-100: } 1 \text { point } \\
\text { KPS 70-80: } 0.5 \\
\text { points KPS }<70: 0 \\
\text { points }\end{array}$ & $\begin{array}{lr}\text { 1: } 1 & \text { point } \\
2-3: & 0.5 \\
\text { points } & >3: 0 \\
\text { points } & \end{array}$ & $\begin{array}{l}\text { Present: } 0 \text { points } \\
\text { Absent: } 1 \text { point }\end{array}$ & NA & $\begin{array}{l}3.5-4 \\
\text { points }(11 \\
\text { mos) }\end{array}$ & $\begin{array}{l}3 \text { points } \\
(8.9 \mathrm{mos})\end{array}$ & $\begin{array}{l}1.5-2.5 \\
\text { points } \\
(3.8 \mathrm{mos})\end{array}$ & $\begin{array}{l}0-1 \\
\text { Points } \\
(2.6 \\
\text { mos })\end{array}$ \\
\hline
\end{tabular}

Abbreviations: BM: Brain metastases, GPA: Graded prognostic assessment, KPS: Karnofsky performance status, RPA: Recursive partitioning analysis, NA: Not applicable

cerebral metastases (ranging from $80.5 \%$ to $93.2 \%$ ), including lung (69.4-75.6\%), followed by bone (18$25.8 \%$ ), lymph nodes, and adrenal glands [2, 3, 12, 30-36]. On the other hand, BMs from early stage HCC or without other extrahepatic metastases are occasionally reported [30]. Moreover, the majority of the available studies reporting that $70 \%$ or more patients had lung metastases. In line with other reports, Seinfeld et al. noted that BM from HCC could be secondary to lung deposits [14, 31, 33]. Therefore, BM should be suspected for patients with extracranial metastasis, especially for metastasis to the lung. Typically, there is a considerable systemic tumor burden in BMHCC patients. Furthermore, the prevalence of extracranial metastases in $\mathrm{BMHCC}$ is higher than the brain metastases from lung cancer, breast cancer and melanoma (Table 2), possibly reflecting a heavier tumor burden among BMHCC patients [27, 37-43].

\section{Number of brain metastases}

Compared with BMs from other types of cancer, most patients with BMHCC have solitary intracranial metastasis (Table 1). The parietal lobe is the most common brain metastasis site, followed by the frontal lobe [3, 17]. Several studies reported a prevalence of single BM from various $\mathrm{BMHCC}$ populations, ranging from $37.1 \%$ to $90.0 \%$, and most of the studies reported an incidence of more than 50\%. By contrast, BMs from lung cancer, breast cancer and melanoma generally had multiple brain lesions (Table 2) [37, 40-42, 44-48].

\section{Clinical presentation}

The neurologic manifestations of HCC include hepatic encephalopathy, paraneoplastic syndromes, and metabolic encephalopathy [17]. The most frequent symptom is hepatic encephalopathy caused by elevated serum ammonia level [49]. In contrast, paraneoplastic syndrome is not common in patients with BMHCC. A specific neurologic paraneoplastic syndrome from $\mathrm{HCC}$ is cerebellar atrophy [49]. Similar to BM from other cancers, there are also some nonspecific symptoms resulting from $\mathrm{BM}$, including intracranial hypertension (space-occupying mass), headache, focal neurological symptoms, and altered consciousness.

By contrast, a remarkable and interesting finding is that patients with BMHCC commonly experience intracerebral hemorrhage $(\mathrm{ICH})$, with the incidence ranging from $33.9 \%$ to $70 \%[3,21,31,33,34,50]$. Given this, sudden onset of symptoms often heralds life threatening $\mathrm{ICH}$. Some experts hold that the hypervascularity of HCC and underlying coagulopathy may explain this observation $[33,34,51]$. ICH usually causes sudden neurologic deterioration and leads to severe neurologic deficits, thus resulting in poor prognosis [31]. However, there is controversy over the effect of ICH on survival among BMHCC patients. Han et al. reported that patients without $\mathrm{ICH}$ had longer survival than patients with ICH (13.7 weeks vs. 8.1 weeks) [2]. On the contrary, Hsieh et al. [52] and Jiang et al. [3] reported that the presence of ICH did not influence the overall survival of patients with BMHCC. More researches are needed to resolve this controversy and explore the underlying mechanisms.

\section{NATURAL COURSE}

Brain metastasis in $\mathrm{HCC}$ patients represent a catastrophic event that portends a uniformly poor prognosis with studies reporting 1- and 5-year survival rates of $2.7 \%$ and $<5 \%$, respectively $[18,21,33]$. With best supportive care only, median survival is just around two weeks[12, 20, 31, 33, 53, 54]. Even with treatment, the prognosis for these patients remains poor with a median survival time that ranges from 4 to 12 weeks (Table 1), with mortality due largely to systemic disease progression or metastatic brain disease $[17,33,35,52]$. This survival seems more dismal than BM from lung cancer, breast cancer and melanoma [55-61]. Encouragingly, in some circumstances, survival could be extended to 12 months after comprehensive treatment [30]. Therefore, a relatively 
Table 4: Two HCC-specific graded prognostic assessment (HCC-GPA) indexes for BMHCC patients

\begin{tabular}{|c|c|c|c|c|c|c|c|c|}
\hline Study & $\begin{array}{l}\text { Performance } \\
\text { status }\end{array}$ & $\begin{array}{l}\text { Child-Pugh } \\
\text { Class }\end{array}$ & \begin{tabular}{|l|} 
Number \\
of brain \\
metastases
\end{tabular} & $\operatorname{AFP}(\mathrm{ng} / \mathrm{ml})$ & Class I & Class II & Class III & Class IV \\
\hline Kim et al.35 & $\begin{array}{l}\text { ECOG } \\
\text { vs } \leq 2\end{array}$ & A vs B/C & $\begin{array}{l}\text { Single vs } \\
\text { Multiple }\end{array}$ & $\begin{array}{l}<1,400 \quad \text { vs } \\
>1,400\end{array}$ & $\begin{array}{l}0-1 \text { risk factor } \\
(5.8 \text { months })\end{array}$ & $\begin{array}{l}2 \text { risk factors } \\
(2.5 \text { months })\end{array}$ & $\begin{array}{l}3-4 \text { risk factors } \\
\text { (0.6 months) }\end{array}$ & NA \\
\hline Lim et al.12 & NA & $\begin{array}{l}\text { A: } 3 \text { points B: } \\
2 \text { points } C: 0 \\
\text { points }\end{array}$ & $\begin{array}{l}\text { Single: } 0.5 \\
\text { points } \\
\text { Multiple:0 } \\
\text { point }\end{array}$ & $\begin{array}{l}<400: 0.5 \\
\text { points } \\
>400: 0 \text { points }\end{array}$ & $\begin{array}{l}4.0 \\
\text { points(27weeks) }\end{array}$ & $\begin{array}{r}3.0-3.5 \\
\operatorname{points}(7.9 \text { weeks })\end{array}$ & $\begin{array}{l}1.5-2.5 \\
\text { points(3.2weeks) }\end{array}$ & $\begin{array}{l}0-1 \\
\text { points(1.7weeks) }\end{array}$ \\
\hline
\end{tabular}

Abbreviations: BMHCC: Brain metastases from hepatocellular carcinoma, GPA: Graded prognostic assessment, ECOG: Eastern Cooperative Oncology Group, NA: Not applicable

better prognosis for patients with BMHCC may be achieved after comprehensive therapy [21].

\section{PROGNOSTIC FACTORS}

Patients with BMHCC usually have poor prognosis and low quality of life (QOL). Many factors, including primary HCC characteristics and clinical variables, could help predict prognosis $[3,12,33,35,53]$. Such variables include performance status (PS), systemic disease status, alpha-fetoprotein (AFP) level, Child-Pugh classification, number of BMs, and treatment modality. AFP reflects the tumor burden and the Child-Pugh classification reflects liver function: these two factors are $\mathrm{HCC}$-specific and their prognostic values have been confirmed in several previous studies $[2,12,33,35,53]$. The number of brain lesions is also an important prognostic factor. Some investigators reported that the median survival of patients with single brain lesions appears to be longer than that of patients with multiple lesions [2, 12, 33, 35, 53]. Additionally, the impact of the presence of extra-cranial metastases on survival remains unclear [3, 21, 33] and further studies are needed to elucidate it.

To predict the prognosis of patients with BMHCC, several prognostic scores including recursive partitioning analysis (RPA), Graded Prognostic Assessment (GPA),

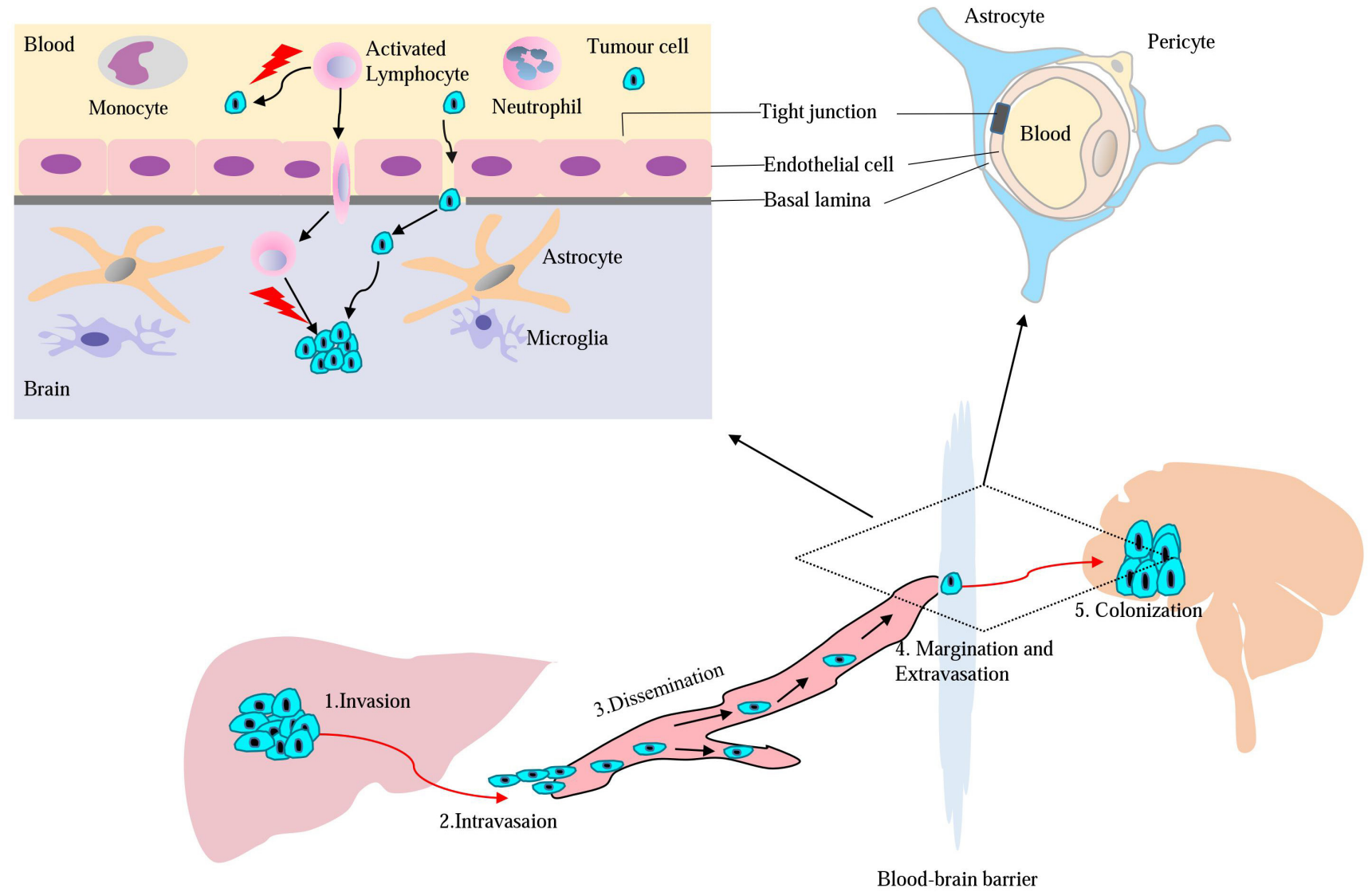

Figure 1: Model for major mechanisms of HCC metastasis to the brain and $\mathrm{T}$ cell pass through blood-brain barrier (BBB). 
Table 5: Summary of published studies of radiosurgery for the treatment of BMHCC

\begin{tabular}{|c|c|c|c|c|c|c|c|c|}
\hline Study (year) & Study design & $\begin{array}{l}\text { Cases } \\
(\mathbf{n} / \mathbf{a})\end{array}$ & $\begin{array}{l}\text { Mets } \\
\text { (n) }\end{array}$ & \begin{tabular}{|l} 
Mean \\
Tumor \\
Volume \\
cm3 \\
(range) \\
\end{tabular} & $\begin{array}{l}\text { Margin } \\
\text { Dose in Gy } \\
\text { (range) }\end{array}$ & $\begin{array}{l}\text { Radiosurgery } \\
\text { regimen(s) }\end{array}$ & $\begin{array}{l}\text { Local } \\
\text { control } \\
(\%)\end{array}$ & $\begin{array}{l}\text { Median } \\
\text { OS(weeks) }\end{array}$ \\
\hline Chang et al.[49](2004) & Retrospective & $1 / 45$ & NA & NA & NA & NA & NA & $>16$ \\
\hline Hiraoka et al.[85] (2008) & Retrospective & 1 & 1 & NA & $35^{*}$ & Cyber-Knife & 100 & NA \\
\hline Choi et al.[33] (2009) & Retrospective & $10 / 62$ & NA & NA & $13.5(10-15)$ & GKS & NA & 10 \\
\hline Han et al.[21] (2010) & Retrospective & $12 / 20$ & 34 & NA & NA & GKS & NA & 16 \\
\hline Jiang et al.[3] (2012) & Retrospective & $9 / 41$ & NA & NA & $16(14-20)$ & NA & NA & 13.5 \\
\hline Han et al.[2] (2013) & Retrospective & $13 / 33$ & NA & NA & $18(14-25)$ & GKS & NA & 10.4 \\
\hline Han et al.[86] (2013) & Retrospective & 32 & 80 & \begin{tabular}{|l|}
6.1 \\
$67.3)$
\end{tabular} & $20.1(10-25)$ & GKS & 51.3 & 11.3 \\
\hline Xu et al.[4] (2014) & Retrospective & 14 & 22 & $\begin{array}{|ll|}8.2 & (0.59- \\
27) & \\
\end{array}$ & $18.7(10-22)$ & GKS & NA & 20 \\
\hline Park et al.[36] (2014) & Retrospective & 73 & 141 & \begin{tabular}{|l|}
$7.3 \quad(0.19-$ \\
$33.7)$
\end{tabular} & $23(15-32)$ & GKS & 79.6 & 16 \\
\hline Kato et al.[105] (2015) & Retrospective & NA & 7 & $\begin{array}{ll}23.5 \\
38) \dagger\end{array} \quad(12-$ & $22(14-30)$ & GKS & $28.6^{* *}$ & NA \\
\hline Yamakawa et al.31 (2015) & Retrospective & $7 / 15$ & NA & $30(5-40) \dagger$ & NA & GKS,SRT & NA & 22.4 \\
\hline
\end{tabular}

Abbreviations: BMHCC: Brain metastases from hepatocellular carcinoma, n/a: Number of patients treated with radiosurgery/ Total number of BMHCC patients, Mets: metastases, OS: Overall survival, RS: Radiosurgery, SRT: Stereotactic radiotherapy, GKS: Gamma knife surgery, NA: Not available, *A margin dose of 35 Gy in 5 fractions was used, $†$ Median size(mm), * *Complete response rate

Basic Score for Brain Metastasis (BSBM), and Score Index for Radiosurgery (SIR), have been devised [62, 63]. The most widely used indices over the last decade were RPA classes and GPA. In the late 1990s, the Radiotherapy Oncology Group (RTOG) first performed a recursive partitioning analysis (RPA) classification including age, Karnofsky Performance Score (KPS), status of primary tumor, and extra-cranial disease. This analysis separated patients into three different classes (RPA classes I, II, and III) (Table 3) [64]. Patients in class I or II showed a longer survival than those in RPA class III (6 months vs. 1 month, $\mathrm{P}<0.0001)$. As RPA does not incorporate the number of brain metastases and some subjective components are difficult to quantify, RTOG subsequently developed a more objective prognostic index called the graded prognostic assessment (GPA) scoring system [53, $64,65]$. Considering that the prognostic factors for BM vary according to primary diagnosis, the original GPA was subsequently modified to diagnosis-specific Graded Prognostic Assessment (DS-GPA) [65]. However, to date only three DS-GPA indices have been developed for BMHCC $[12,35,53]$. In 2014, two studies conducted in Korea focused on BMHCC (summarized in Table 4). Kim et al. [35] assigned patients into three groups according to Eastern Cooperative Oncology Group performance status (ECOG PS), Child-Pugh class, AFP level, and number of brain lesions. Another study conducted by Lim et al. [12] assigned a score from 0 to 4 based on number of brain metastases, AFP, and Child-Pugh grade. This score system was independently validated in a cohort of 25 patients. One year later, a nomogram taking into account four variables (ECOG PS, Child-Pugh classification, AFP, and treatment aim) was developed [53]. Compared with other prognostic indices, the nomogram provides an individualized estimate of survival with a high concordance probability and may help more precise and individualized management of patients [66].

It should be noted that RPA and GPA are not diagnosis specific and were not validated in $\mathrm{BMHCC}$ patients. Furthermore, HCC is a very heterogeneous tumor, therefore further studies are warranted to verify their clinical application in BMHCC patients. The three HCC-GPA models were all developed from small-scale retrospective studies rather than a prospective randomized trial. Because of the weak statistical power, further studies to verify and develop new models are needed. Nonetheless, these tools may still help clinicians stratify patients and select appropriate therapy for BMHCC patients.

\section{DIAGNOSIS OF BMHCC}

Because BMHCC usually carry a substantial 
morbidity and mortality rate, therefore early diagnosis is very important for improving the prognosis. Computed tomography (CT) and magnetic resonance imaging (MRI) are the two most commonly used imaging modalities for detecting brain lesions $[67,68]$. The use of CT as a central nervous system (CNS) imaging modality has gradually declined over the last 30 years and has been largely replaced by MRI [68]. MRI can detect most of BMs and its sensitivity and specificity is markedly greater than that of $\mathrm{CT}$, particularly when the lesions are very small or located in the posterior fossa $[46,69,70]$. MRI may be useful for differential diagnosis between primary brain tumors and BM, and careful staging can often detect a peripheral source of BM so brain biopsy is usually unnecessary [69]. Generally, MRI is recommended as the first-line imaging modality for potential BM [71, 72]. However, although MR imaging is the preferred imaging modality, CT remains a vital tool for initial work-up and perioperative management [73]. It is extremely useful for patients who present with new focal deficits because it is easily performed, well tolerated, and can rapidly rule out life-threatening emergencies such as hemorrhage, hydrocephalus, and significant mass effect [73]. Given the propensity of this vascular tumor to hemorrhage, CT may play a more important role in BMHCC patients than in BMs from other cancers. The role of routine screening of asymptomatic HCC patients for the development of BM by imaging remains controversial since no study has investigated whether effective screening can prolong overall survival (OS) and prevent serious symptoms [70]. Studies focusing on this issue are urgently needed.

\section{MANAGEMENT OF BMHCC}

\section{Principles and goals of treatment}

Because of the rarity and poor prognosis of $\mathrm{BMHCC}$, guidelines on diagnosis and therapeutic strategy have not been established. The treatment approach for BMHCC may be similar to general guidelines for metastatic brain tumors [2]. Optimal treatment requires an individualized process for each patient, depending on the patient's clinical status (e.g., neurologic deficit, Child-Pugh class, life expectancy), disease burden (AFP level, extracranial disease control, especially the number of BMs), and characteristics of the primary HCC (radiologic aspect, size, location) [12, 53, 74]. Therefore, an integrative multidisciplinary approach for each case from diagnosis to treatment is always recommended $[62,74]$. Current options include surgery, whole-brain radiation therapy (WBRT), stereotactic radiosurgery (SRS), chemotherapy, targeted agents, immunotherapy, and supportive measures. With respect to treatment goals, for patients with favorable prognostic factors who might benefit from an aggressive treatment, the goal of treatment is to prolong survival and improve QOL, whereas for those with short survival expectancy, stabilizing BMs and palliating symptoms is warranted [74].

\section{Local treatment of BMHCC}

WBRT, SRS, and surgical resection are the current options for treatment of BM. Unfortunately, BMHCC

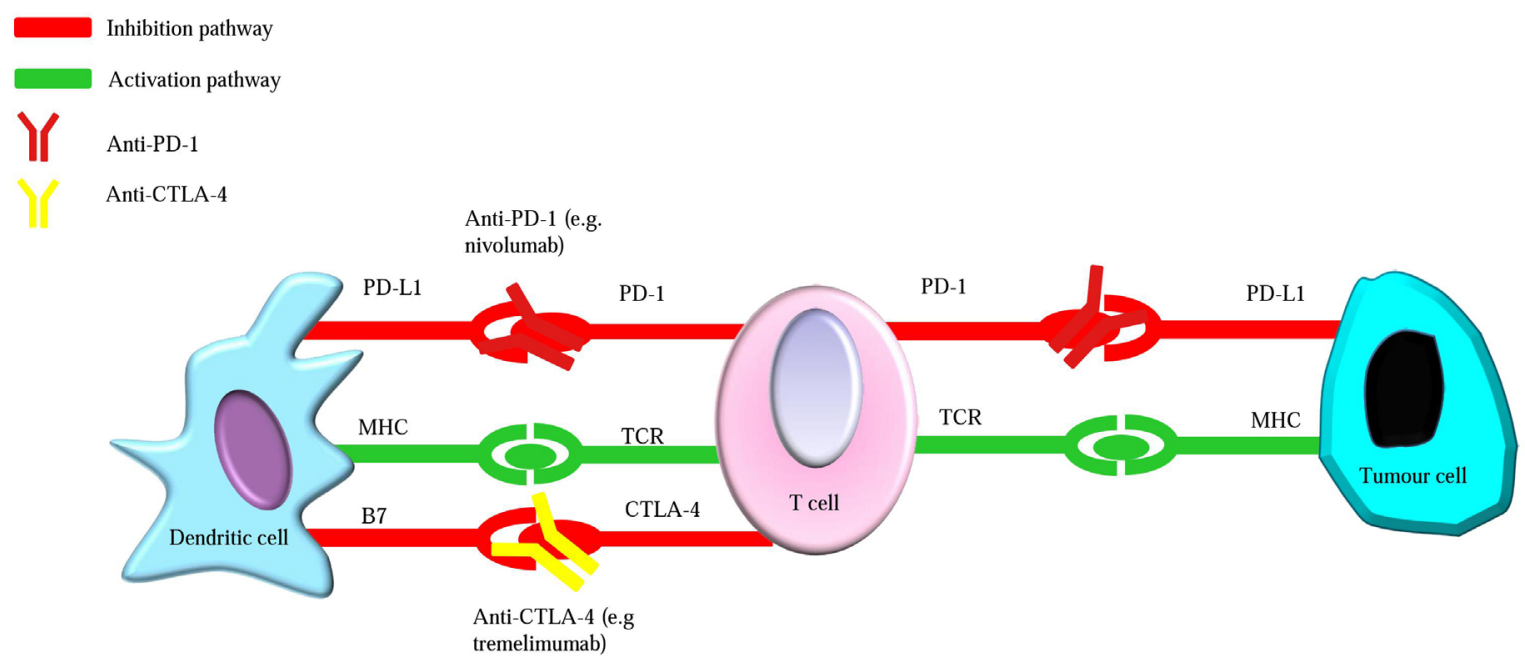

Figure 2: Simplified mechanism of CTLA-4 and PD-1 inhibitors in tumor immunotherapy. T cell activation leads to the up-regulation of immune checkpoint molecules such as CTLA-4 and PD-1 which act to abrogate T cell responses. Anti-CTLA-4 and antiPD-1 antibodies reverse the immunosuppressive effect when they bind CTLA-4 receptors and PD-1 on T cells, respectively. CTLA-4, T-lymphocyte antigen-4; PD-1, programmed death 1; PD-L1, programed death-ligand-1; MHC, major histocompatibility complex; TCR, T cell receptor. Notably, the scheme is highly simplified: in reality CTLA-4 and PD-1 act through multiple mechanisms. 
usually occurs in cases of advanced HCC and the patients tend to show a considerable deterioration in PS. Consequently, locoregional treatment may not lead to a clinical benefit and/or gain in survival.

\section{Surgical resection}

National guidelines recommend that surgery should be considered for the management of BM patients with single or few $(\leq 3)$ lesions, particularly when the systemic disease is well controlled and the BMs are symptomatic $[72,75]$. Surgical resection not only can lead to an immediate elimination of life-threatening status and symptom-generating mass effect, but also a reduction of focal neurologic deficits and a rapid steroid taper $[5,74]$. Compared with best supportive care, surgical metastectomy has been shown to provide a significantly prolonged survival benefit ( $>3$ months vs. $<2$ weeks) in $\mathrm{BMHCC}$ patients in multiple retrospective series $[2,33,34]$. Surgery is recommended in cases with a limited number of lesions $(\leq 3)$, younger patients, and those with good KPS [36, 72, 75]. However, surgery is also recommended to palliate symptoms in cases with a single large metastasis $(>3 \mathrm{~cm})$ and a significant mass effect (1-cm midline shift). It is generally thought to improve QOL despite the lack of a survival benefit [26, 36]. Although more than half of patients presented with single intracranial metastasis [10, 17, 21, 49], only a small proportion $(<15 \%)$ underwent surgical resection because of considerable liver function deterioration and other medical problems [2, 33, 35]. Nevertheless, surgical resection remains an appropriate therapeutic option for eligible patients with BMHCC.

\section{RADIOTHERAPY}

\section{WBRT}

WBRT has been used as the principal treatment for multiple $(\geq 4)$ brain metastases or as an adjuvant treatment $[20,76]$. Considering the acute adverse effects (fatigue, alopecia, Eustachian tube dysfunction) and late neurotoxicity associated with WBRT, this approach is usually not recommended unless necessary [77]. Historically, WBRT alone is used to provide relief of symptoms in patients for whom surgery and SRS are contraindicated [26], although it may not alter the survival of these patients $[62,78]$. Recently a phase III randomized trial suggested that WBRT provides little clinical benefit compared to supportive care for patients with non-small cell lung cancer (NSCLC) and BM who are aged $>60$ years and have KPS $<70$ [79], therefore WBRT should be used with great caution.

\section{Adjuvant WBRT}

There is still controversy over whether adjuvant WBRT results in a clinical advantage for patients, especially those with poor prognosis [63, 72]. Most studies (reviewed in [26, 62, 72, 78, 80, 81])have clearly demonstrated that the addition of WBRT to surgery or SRS was associated with improved local control rates and decreased neurologic deaths but did not improve outcome in terms of survival (class I evidence). With respect to $\mathrm{BMHCC}$, a retrospective study by Choi et al. [33] concluded that resection in conjunction with WBRT showed considerably prolonged survival (33.6 weeks). Despite the lack of a survival benefit, it is now generally accepted that adjuvant WBRT can be considered in the case of absent/controlled systemic disease and good PS (KPS > 70) [72]. Considering the established potential adverse effects of WBRT, omission of WBRT appears to be attractive in patients with a limited number of BM [80]. Moreover, it is noteworthy that a retrospective study from Japan showed that radiotherapy could prevent intracranial hemorrhage and improve survival [31]. Recently, Kim et al. [50] also concluded a similar result through retrospective analysis though statistical significance was not reached. As mentioned above, BMHCC is frequently to be accompanied by $\mathrm{ICH}$, whereas optimal management of this scenario has not been established. Given the peculiarity of BMHCC, WBRT appears to be an important strategy to improve survival through preventing $\mathrm{ICH}$. However, more studies are needed to offer definitive conclusions.

\section{Stereotactic radiosurgery}

SRS permits the delivery of high doses of radiation to a small target $(<3.5 \mathrm{~cm})$ using gamma-knife $(\mathrm{GK})$ or a linear accelerator (Linac) $[72,77]$. SRS has become an increasingly popular treatment option for patients with 1-4 metastases [81], and can be considered as an alternative for surgery or a salvage treatment in patients who are not candidates for surgery [74, 82-84]. Typically, when the metastases are larger than 3-4 cm or immediate mass relief is required, surgery is preferred $[63,74]$. Recently, postoperative SRS to the surgical cavity is becoming popular since it could maximize local control. In contrast to WBRT, SRS might avoid late neurocognitive effects [77]. However, only a limited number of retrospective studies have specifically assessed radiotherapy of BMHCC (summarized in Table 5). Of note, due to the risk of CNS radiation toxicity in accordance with the RTOG 90-05 dosing guideline, most reports suggest a prescribed mean dose of $<20 \mathrm{~Gy}$, whereas the estimated biologically effective dose for HCC tumor is approximately $20 \mathrm{~Gy}$ or more (Table 5). A few studies have demonstrated that the marginal dose more than 20 Gy appears to be sufficient to 
control BMHCC and preserve neurologic function $[4,85$, 86]; however, the evidence is not solid and the optimal dose is not yet clearly defined.

\section{Cyber-knife (CK)}

Cyber-knife (CK), a robotic image-guided system, has been successfully used in many types of tumor including brain cancer, liver cancer, and other types of cancer [87-90]. In 2008, Hiraoka et al. [85] first reported the use of cyber-knife for BMHCC, and showed that it provided excellent local control with acceptable toxicity and could also prevent re-hemorrhage. Compared with GK, CK is a relatively non-invasive treatment modality. It could provide more accurate target localization, higher tumor control, and lower toxicity with repeated treatments for recurrent metastases $[88,91]$. To date, there is robust evidence supporting the efficacy of $\mathrm{CK}$ in treating $\mathrm{BM}$ from different primary cancers. Thus, $\mathrm{CK}$ appears as a promising strategy for treating BMHCC patients, not yet sufficiently supported by convincing clinical data in this population.

\section{Cytotoxic chemotherapy}

HCC is known to be a relatively chemotherapyresistant tumor. Conventional cytotoxic chemotherapy has not been proved to prolong the overall survival for any subset of HCC $[92,93]$. The choice and efficacy of chemotherapy depend on chemosensitivity of the primary tumor. In addition, the brain is difficult to access for chemotherapeutic drugs due to limited penetration through the BBB $[20,94]$. Therefore, chemotherapy may be not suitable for treatment of BMHCC.

\section{Supportive care}

The survival of BMHCC patients is poor, with a mean survival period of 3 months. Patients with poor prognosis should be managed supportively $[79,95,96]$. Although therapies and technologies have improved a lot, in past studies at least $18-40 \%$ of BMHCC patients received conservative care $[2,12,33,34]$. Thus, effective supportive treatment, including glucocorticoids, antiepileptic drugs (AEDs), and anticoagulant medications, is critical for BMHCC patients and could improve QOL [77, 97].

As reported in available literatures, the majority of cases of BM with cerebral edema have been managed with glucocorticoids, which could improve related symptoms[72, 76]. Dexamethasone is generally considered the steroid of choice, mainly because of its relatively low mineralocorticoid activity, long half-life, and decreased risk of cognitive impairment [76, 77]. A marked neurologic improvement is expected within 24$72 \mathrm{~h}$ after dexamethasone use in up to $75 \%$ of patients with brain metastases [98]. The recommended starting dose depends on the severity of symptoms. Guidelines support an initial dexamethasone dose of 4-8 $\mathrm{mg}$ per day in two divided doses; however, these recommendations are based on level 2-3 evidence [72, 98]. For severe symptoms related to increased intracranial pressure (ICP), a starting dose of $16 \mathrm{mg} / \mathrm{d}$ or more should be considered [98]. As dexamethasone is effectively eliminated by hepatic mechanisms and up to $40 \%$ of BMHCC patients have poor liver function (Child-Pugh classification B/C) [3, 33, $35]$, so dosage adjustment may be required in this group of patients.

Patients with seizures should be treated with standard AEDs. There is no evidence that prophylactic use of AEDs can prevent future seizures, therefore it is not recommended in asymptomatic patients $[72,74$, $76,77]$. As short-term prophylactic AED use with rapid tapering off reduces the risk of seizures by $40-50 \%$ within the first postoperative week, the American Association of Neurology recommends tapering of prophylactic AEDs after the first postoperative week in the perioperative setting [99].

Venous thromboembolism (VTE) is common in cancer patients, especially in patients with brain tumors. It is considered as the second leading cause of death among this population [100,101]. The management of BMHCC patients is particularly challenging because of the high risk of ICH and poor liver function, and no data are available on the clinical scenario. A single-center retrospective study demonstrated that anticoagulation did not significantly increase the risk of intracranial hemorrhage for melanoma patients with hemorrhagic BM and guidelines recommend anticoagulant treatment for patients with brain metastases [72]. However, there is no evidence regarding the safety of anticoagulation therapy in BMHCC patients and use of anticoagulants in BMHCC merits careful consideration.

\section{Novel treatments}

Although many patients may not be suitable for resection or radiotherapy, some novel treatments show great promise for the management of BMHCC.

\section{Targeted therapy}

Targeted therapy has recently emerged as an important modality for the treatment of BM from different types of tumors. Several prospective trials have shown unequivocal clinical activity in melanoma and NSCLC (reviewed in [77]). Many trials are focusing on molecular targeted agents in HCC, but most have ended in failure except sorafenib $[102,103]$ and even this agent shows only a limited increase in survival of approximately 
3 months for advanced HCC [104]. Disappointingly, however, BM is a contraindication for sorafenib [105]. In addition, because of the diversity of the carcinogenesis mechanisms of HCC, most molecular targeted agents provide only partial inhibition of signaling pathways [106109] and combinatorial approaches with other therapies may be more appropriate.

\section{Immunotherapy}

Immunotherapy is emerging as a promising treatment for intractable cancers such as hematologic malignancies, melanoma, and other solid cancers [82, $110,111]$. Among immunotherapies, adoptive cell therapy (ACT) and immune checkpoint blockade are hot research areas.

\section{Adoptive cell therapy (ACT)}

ACT is a highly personalized form of passive immunization in which tumor cells are destroyed following the infusion of autologous or redirected tumorspecific T cells [112]. ACT has shown encouraging therapeutic efficacy in the treatment of a variety types of cancers including brain metastases [112-114]. Moreover, many clinical trials also have demonstrated that ACT showed promising antitumor effects against HCC. Recently, a review conducted by Liu et al. [115] concluded that about half of immunotherapy clinical trials in HCC involve ACT and its use can significantly improve the recurrence and survival of HCC. Preliminary results of a recently published phase I trial showed that ACT was safe and most of the patients had no disease progression at a median follow-up of 14 months [116]. Although there is no research available concerning the effect of ACT in BMHCC, ACT has been proved to eradicate metastatic tumor cells [111]. Recent advances demonstrated that ACT was capable of abrogating brain metastases from melanoma with complete and durable responses [114, 117]. Because several studies have demonstrated that activated $\mathrm{T}$ cells could pass through the BBB and remain active (Figure 1) [118, 119], based on the satisfactory effects in BMs and $\mathrm{HCC}$ we can hypothesize that ACT may be effective in BMHCC. Ongoing and future research studies are expected to provide more data on this topic.

\section{Immune checkpoint blockade}

The balance between co-stimulatory and coinhibitory signals, defined as "immune checkpoints", determines cytotoxic T-cell activation and the intensity of the immune response [120]. T-lymphocyte antigen-4 (CTLA-4) and programmed death 1 (PD-1) are two of most prevalent immune checkpoint proteins. The mechanisms of CTLA-4 and PD-1 and their possible roles in treating $\mathrm{HCC}$ were recently reviewed (Figure 2) [121]. The CTLA-4 inhibitor tremelimumab showed a favorable safety profile and significant antitumor effects against advanced $\mathrm{HCC}$, with a $76 \%$ disease control rate in a phase I clinical trial [122]. A phase I/II clinical trial is currently ongoing to test the safety and antitumor activity of an anti-PD-1 antibody (nivolumab) for advanced HCC (NCT01658878). The interim findings were presented at the 2016 ASCO Annual Meeting [123]. Investigators demonstrated that the treatment was well tolerated with a manageable safety profile and the estimated survival rate in evaluable patients $(\mathrm{n}=48)$ was $59 \%$ at 12 months. Another phase III study to determine whether nivolumab or sorafenib is more effective in the treatment of advanced HCC was initiated in 2015 and is currently ongoing (NCT02576509). The initial findings were announced at the 2016 International Liver Cancer Association Annual Conference, showing an encouraging 9-month overall survival rate of $71 \%(n=214)$ with a favorable safety profile [124]. In addition, immune checkpoint inhibitors have shown impressive clinical efficacy in brain metastases from melanoma and NSCLC in early clinical trials [125-131]. Based on these results, we have great confidence for future use of checkpoint blockers in the treatment of BMHCC. Furthermore, accumulating preclinical and observational data suggest that the integration of immunotherapy and radiation therapy has notable clinical efficacy in brain metastases [128, 132]. Further clinical results will help elucidate the role of this novel combination.

\section{CONCLUSIONS \& FUTURE PERSPECTIVES}

Brain metastases represent a critical stage of HCC and the frequency is expected to increase. Therefore, it is increasingly important for physicians to understand its characteristics, implications, and potential treatments. Comparing with $\mathrm{BM}$ from other types of cancer, BMHCC tend to confer a worse prognosis due to heavier systemic tumor burden, severe underlying liver dysfunction and much higher incidence of ICH. Consequently, a considerable proportion of BMHCC patients are not eligible for any treatment but supportive care. Given the high prevalence of $\mathrm{ICH}$, the using of anticoagulants in BMHCC patients merits careful consideration and there is an urgent need for effective therapies to prevent $\mathrm{ICH}$. Based on current evidence, in cases with a limited number of lesions $(\leq 3)$, good prognostic factors, and controlled systemic disease, surgery is recommended. WBRT remains a standard option for patients with limited performance status and/or multiple metastases, may reduce the incidence of ICH and warrants further clinical investigation. The development of $\mathrm{CK}$ has also contribute to local control of this disease. Chemotherapy and targeted therapy have limited efficacy on BMHCC. Notably, 
immunotherapy has the potential to achieve complete, long-lasting remissions and cancer cures, representing the most promising cancer treatment approach. Currently, combinatorial therapy is considered as a promising strategy for cancer treatment. Nonetheless, the optimal sequence and/or combination of the available treatment modalities requires further exploration.

\section{ACKNOWLEDGMENTS}

This work was supported by International Science and Technology Cooperation Projects (2016YFE0107100, 2015DFA30650 and 2010DFB33720), Capital Special Research Project for Health Development (2014-2-4012), Capital research project for the characteristics clinical application (Z151100004015170) and Program for New Century Excellent Talents in University (NCET-11-0288).

\section{CONFLICTS OF INTEREST}

There is no conflict of interests to disclose.

\section{REFERENCES}

1. Menis J, Fontanella C, Follador A, Fasola G, Aprile G. Brain metastases from gastrointestinal tumours: tailoring the approach to maximize the outcome. Crit Rev Oncol Hematol. 2013; 85: 32-44. doi: 10.1016/j. critrevonc.2012.04.001.

2. Han MS, Moon KS, Lee KH, Cho SB, Lim SH, Jang WY, Jung TY, Kim IY, Jung S. Brain metastasis from hepatocellular carcinoma: the role of surgery as a prognostic factor. Bmc Cancer. 2013; 13: 349-54.

3. Jiang XB, Ke C, Zhang GH, Zhang XH, Ke S, Chen ZP, Mou YG. Brain metastases from hepatocellular carcinoma: clinical features and prognostic factors. Bmc Cancer. 2012; 12: 1-9.

4. Xu Q, Pan W, Feng Y, Ke Y, Ying T, Zhou Y. Gamma Knife Surgery for Brain Metastasis from Hepatocellular Carcinoma. Plos One. 2014; 9: e88317.

5. Ahluwalia MS, Vogelbaum MV, Chao ST, Mehta MM. Brain metastasis and treatment. F1000 Prime Reports. 2014; 6.

6. Seoane J, De Mattos-Arruda L. Brain metastasis: new opportunities to tackle therapeutic resistance. Mol Oncol. 2014; 8: 1120-31. doi: 10.1016/j.molonc.2014.05.009.

7. Caffo O, Veccia A, Russo L, Galligioni E. Brain metastases from prostate cancer: an emerging clinical problem with implications for the future therapeutic scenario. Future Oncology. 2012; 8: 1585-95.

8. Peters S, Bexelius C, Munk V, Leighl N. The impact of brain metastasis on quality of life, resource utilization and survival in patients with non-small-cell lung cancer. Cancer Treatment Reviews. 2016; 45: 139-62.
9. Chamberlain MC, Baik CS, Gadi VK, Bhatia S, Chow LQM. Systemic therapy of brain metastases: non-small cell lung cancer, breast cancer, and melanoma. 2017.

10. Chan KM. Efficacy of surgical resection in management of isolated extrahepatic metastases of hepatocellular carcinoma. World Journal of Gastroenterology. 2009; 15: 5481. doi: 10.3748/wjg.15.5481.

11. Kim M, Na DL, Park SH, Jeon BS, Roh JK. Nervous system involvement by metastatic hepatocellular carcinoma. Journal of Neuro-Oncology. 1998; 36: 85-90.

12. Lim S, Lee S, Lim JY, Park JS, Seong JS, Chang WS, Han $\mathrm{KH}$, Choi HJ. Hepatocellular carcinoma specific graded prognostic assessment can predict outcomes for patients with brain metastases from hepatocellular carcinoma. J Neurooncol. 2014; 120: 199-207. doi: 10.1007/s11060-0141546-7.

13. Natsuizaka M, Omura T, Akaike T, Kuwata Y, Yamazaki K, Sato T, Karino Y, Toyota J, Suga T, Asaka M. Clinical features of hepatocellular carcinoma with extrahepatic metastases. J Gastroenterol Hepatol. 2005; 20: 1781-7. doi: 10.1111/j.1440-1746.2005.03919.x.

14. Seinfeld J, Wagner AS, Kleinschmidt-DeMasters BK. Brain metastases from hepatocellular carcinoma in US patients. J Neurooncol. 2006; 76: 93-8. doi: 10.1007/s11060-0054175-3.

15. Murakami K, Nawano S, Moriyama N, Sekiguchi R, Satake M, Fujimoto H, Ichikawa T. Intracranial metastases of hepatocellular carcinoma: CT and MRI. Neuroradiology. 1996; 38 Suppl 1: S31-S5.

16. Chen SF, Tsai NW, Lui CC, Lu CH, Huang CR, Chuang YC, Cheng YF, Kuo CH, Chang WN. Hepatocellular carcinoma presenting as nervous system involvement. European Journal of Neurology. 2007; 14: 408-12.

17. Hsiao SY, Chen SF, Chang $\mathrm{CC}$, Lin $\mathrm{CH}$, Chang WN, $\mathrm{Lu} \mathrm{CH}$, Chuang YC, Tsai NW. Central nervous system involvement in hepatocellular carcinoma: clinical characteristics and comparison of intracranial and spinal metastatic groups. J Clin Neurosci. 2011; 18: 364-8. doi: 10.1016/j.jocn.2010.04.037.

18. Shao YY, Lu LC, Cheng AL, Hsu CH. Increasing incidence of brain metastasis in patients with advanced hepatocellular carcinoma in the era of antiangiogenic targeted therapy. Oncologist. 2011; 16: 82-6. doi: 10.1634/ theoncologist.2010-0272.

19. Nieder C, Spanne O, Mehta MP, Grosu AL, Hans Geinitz MD. Presentation, patterns of care, and survival in patients with brain metastases. Cancer. 2011; 117: 2505-12.

20. Owonikoko TK, Arbiser J, Zelnak A, Shu HK, Shim H, Robin AM, Kalkanis SN, Whitsett TG, Salhia B, Tran NL, Ryken T, Moore MK, Egan KM, et al. Current approaches to the treatment of metastatic brain tumours. Nat Rev Clin Oncol. 2014; 11: 203-22. doi: 10.1038/nrclinonc.2014.25.

21. Han JH, Dong GK, Park JC, Chung HT, Sun HP, Chung YS. Little Response of Cerebral Metastasis from 
Hepatocellular Carcinoma to Any Treatments. Journal of Korean Neurosurgical Society. 2010; 47: 325-31.

22. Kumar M, Panda D. Role of Supportive Care for Terminal Stage Hepatocellular Carcinoma. Journal of Clinical \& Experimental Hepatology. 2014; 4: 130-9.

23. Johung KL, Yeh N, Desai NB, Williams TM, Lautenschlaeger T, Arvold ND, Ning MS, Attia A, Lovly CM, Goldberg S. Extended Survival and Prognostic Factors for Patients With ALK-Rearranged Non-Small-Cell Lung Cancer and Brain Metastasis. Journal of Clinical Oncology Official Journal of the American Society of Clinical Oncology. 2016; 34: 123.

24. Chi A, Komaki R. Treatment of Brain Metastasis from Lung Cancer. Progress in Neurological Surgery. 2010; 25: 14855.

25. Leone JP, Leone BA. Breast cancer brain metastases: the last frontier. Experimental Hematology \& Oncology. 2015; 4: 1-10.

26. Sim HW, Morris PG, Patil S, Khasraw M. Brain metastases in breast cancer. Expert Rev Anticancer Ther. 2014; 14: 173-83. doi: 10.1586/14737140.2014.863468.

27. Lee SS, Ahn JH, Kim MK, Sym SJ, Gong G, Ahn SD, Kim $\mathrm{SB}$, Kim WK. Brain metastases in breast cancer: prognostic factors and management. Breast Cancer Research and Treatment. 2008; 111: 523-30.

28. Sampson JH, Shafman TD, Carter JH, Friedman AH, Seigler HF. Brain metastases from malignant melanoma. 2005.

29. Daryanani D, Ma PJJ, Haaxma RH, Nap R, Kuiper H, Hoekstra HJ. Increased incidence of brain metastases in cutaneous head and neck melanoma. Melanoma Research. 2005; 15: 119-24.

30. Toshikuni N, Morii K, Yamamoto M. Radiotherapy for multiple brain metastases from hepatocellular carcinomas. World Journal of Gastroenterology. 2007; 13: 4520-2.

31. Yamakawa Y, Moriguchi M, Aramaki T, Mitsuya K, Asakura K, Sawada A, Endo M, Nakasu Y. Brain metastasis from hepatocellular carcinoma: The impact of radiotherapy on control of intracranial hemorrhage. Hepatol Res. 2015; 45: 1071-5. doi: 10.1111/hepr.12457.

32. Katyal S, Rd OJ, Peterson MS, Ferris JV, Carr BS, Baron RL. Extrahepatic metastases of hepatocellular carcinoma. Radiology. 2000; 216: 698-703.

33. Choi HJ, Cho BC, Sohn JH, Shin SJ, Kim SH, Kim JH, Yoo NC. Brain metastases from hepatocellular carcinoma: prognostic factors and outcome: brain metastasis from HCC. J Neurooncol. 2009; 91: 307-13. doi: 10.1007/ s11060-008-9713-3.

34. Park TY, Na YC, Lee WH, Ji HK, Chang WS, Jung $\mathrm{HH}$, Chang JH, Jin WC, Park YG. Treatment Options of Metastatic Brain Tumors from Hepatocellular Carcinoma: Surgical Resection vs. Gamma Knife Radiosurgery vs. Whole Brain Radiation Therapy. Brain Tumor Research \& Treatment. 2013; 1: 78-84.
35. Kim KS, Kim K, Chie EK, Kim YJ, Yoon JH, Lee HS, Ha SW. Prognostic stratification of brain metastases from hepatocellular carcinoma. J Neurooncol. 2014; 120: 209-14. doi: 10.1007/s11060-014-1547-6.

36. Park ES, Kwon DH, Park JB, Lee DH, Cho YH, Kim JH, Kim CJ. Gamma Knife surgery for treating brain metastases arising from hepatocellular carcinomas. J Neurosurg. 2014; 121 Suppl: 102-9. doi: 10.3171/2014.7.GKS141507.

37. Gaspar LE, Mehta MP, Patchell RA, Burri SH, Robinson PD, Morris RE, Ammirati M, Andrews DW, Asher AL, Cobbs CS. The role of whole brain radiation therapy in the management of newly diagnosed brain metastases: a systematic review and evidence-based clinical practice guideline. Journal of Neuro-Oncology. 2010; 96: 57.

38. Enders F, Geisenberger C, Jungk C, Bermejo JL, Warta R, Von DA, Herold-Mende C, Unterberg A. Prognostic factors and long-term survival in surgically treated brain metastases from non-small cell lung cancer. Clinical Neurology \& Neurosurgery. 2016; 142: 72.

39. Guo S, Reddy CA, Chao ST, Suh JH. Impact of non-small cell lung cancer histology on survival predicted from the graded prognostic assessment for patients with brain metastases. Lung Cancer. 2012; 77: 389-93.

40. Won YK, Lee JY, Kang YN, Jang JS, Kang JH, Jung SL, Sung SY, Jo IY, Park HH, Lee DS. Stereotactic radiosurgery for brain metastasis in non-small cell lung cancer. Radiation Oncology Journal. 2015; 33: 207-16.

41. Anders CK, Deal AM, Miller CR, Khorram C, Meng H, Burrows E, Livasy C, Fritchie K, Ewend MG, Perou CM, Carey LA. The prognostic contribution of clinical breast cancer subtype, age, and race among patients with breast cancer brain metastases. Cancer. 2011; 117: 1602-11.

42. Mckee MJ, Keith K, Deal AM, Garrett AL, Wheless AA, Green RL, Benbow JM, Dees EC, Carey LA, Ewend MG. A Multidisciplinary Breast Cancer Brain Metastases Clinic: The University of North Carolina Experience. Oncologist. 2016; 21: 16-20.

43. Radbill AE, Fiveash JF, Falkenberg ET, Guthrie BL, Young PE, Meleth S, Markert JM. Initial treatment of melanoma brain metastases using gamma knife radiosurgery: an evaluation of efficacy and toxicity. Cancer. 2004; 101: 82533.

44. Bender ET, Tomé WA. Distribution of brain metastases: implications for non-uniform dose prescriptions. British Journal of Radiology. 2011; 84: 649-58.

45. Rava P, Sioshansi S, Dipetrillo T, Cosgrove R, Melhus C, Wu J, Mignano J, Wazer DE, Hepel JT. Local recurrence and survival following stereotactic radiosurgery for brain metastases from small cell lung cancer. Practical Radiation Oncology. 2015; 5: e37-e44.

46. Gil-Gil MJ, Martinez-Garcia M, Sierra A, Conesa G, Del Barco S, Gonzalez-Jimenez S, Villa S. Breast cancer brain metastases: a review of the literature and a current multidisciplinary management guideline. Clin Transl Oncol. 
2014; 16: 436-46. doi: 10.1007/s12094-013-1110-5.

47. Ajithkumar T, Parkinson C, Fife K, Corrie P, Jefferies S. Evolving treatment options for melanoma brain metastases. Lancet Oncology. 2015; 16: e486-e97.

48. Harrison BE, Johnson JL, Clough RW, Halperin EC. Selection of patients with melanoma brain metastases for aggressive treatment. American Journal of Clinical Oncology. 2003; 26: 354-7.

49. Chang L, Chen YL, Kao MC. Intracranial metastasis of hepatocellular carcinoma: review of 45 cases. Surg Neurol. 2004; 62: 172-7. doi: 10.1016/j.surneu.2003.10.002.

50. Kim KS, Kim K, Chie EK, Kim YJ, Yoon JH, Lee HS, Ha SW. Post-treatment intracranial hemorrhage of brain metastases from hepatocellular carcinoma. Journal of Business. 2015; 33: 36-41.

51. Uchino K, Tateishi R, Shiina S, Kanda M, Masuzaki R, Kondo Y, Goto T, Omata M, Yoshida H, Koike K. Hepatocellular carcinoma with extrahepatic metastasis: clinical features and prognostic factors. Cancer. 2011; 117: 4475-83.

52. Hsieh $\mathrm{MJ}, \mathrm{Lu} \mathrm{CH}$, Tsai NW, Lui CC, Chuang YC, Huang CR, Chen SF, Chang CC, Chang HW, Chang WN. Prediction, clinical characteristics and prognosis of intracerebral hemorrhage in hepatocellular carcinoma patients with intracerebral metastasis. J Clin Neurosci. 2009; 16: 394-8. doi: 10.1016/j.jocn.2008.05.010.

53. Park Y, Kim KS, Kim K, Chie EK, Kim JH, Kim JS, Kim TH, Kim DY, Jang WI, Kim MS, Koo TR, Chang AR. Nomogram prediction of survival in patients with brain metastases from hepatocellular carcinoma treated with whole-brain radiotherapy: a multicenter retrospective study. J Neurooncol. 2015; 125: 377-83. doi: 10.1007/s11060-0151926-7.

54. Bartelt S, Momm F, Weissenberger C, Lutterbach J. Patients with brain metastases from gastrointestinal tract cancer treated with whole brain radiation therapy:Prognostic factors and survival. World Journal of Gastroenterology. 2004; 10: 3345 .

55. Melisko ME, Kunwar S, Prados M, Berger MS, Park JW. Brain metastases of breast cancer. Breast Disease. 2005; 26: 139-47.

56. Ceresoli GL, Cappuzzo F, Gregorc V, Bartolini S, Crinò L, Villa E. Gefitinib in patients with brain metastases from non-small-cell lung cancer: a prospective trial. Annals of Oncology. 2004; 15: 1042.

57. Schuette W. Treatment of brain metastases from lung cancer: chemotherapy. Lung Cancer. 2004; 45: S253-7.

58. Tibdewal AR, Pathak RS, Laskar SG, Agarwal JP. Prognostic Factors and Survival Outcomes of Lung Cancer Patients withBrain Metastasis: Experience of a Tertiary Cancer Centre. 2016.

59. Peuvrel L, Saint-Jean M, Quéreux G, Brocard A, Khammari A, Knol AC, Dréno B. Incidence and characteristics of melanoma brain metastases developing during treatment with vemurafenib. Journal of Neuro-Oncology. 2014; 120: 147-54.

60. Yamanaka R. Medical management of brain metastases from lung cancer (Review). Oncology Reports. 2009; 22: $1269-76$

61. Hong A, Fogarty G, Izard MA. The role of radiation therapy in the management of metastatic melanoma in the brain. International Journal of Surgical Oncology. 2012; 2012: 294735.

62. Dawe DE, Greenspoon JN, Ellis PM. Brain metastases in non-small-cell lung cancer. Clin Lung Cancer. 2014; 15: 249-57. doi: 10.1016/j.cllc.2014.04.008.

63. Kaal ECA, Niël CGJH, Vecht CJ. Therapeutic management of brain metastasis. The Lancet Neurology. 2005; 4: 289-98. doi: 10.1016/s1474-4422(05)70072-7.

64. Gaspar LE, Scott C, Murray K, Curran W. Validation of the RTOG recursive partitioning analysis (RPA) classification for brain metastases. International Journal of Radiation Oncologybiologyphysics. 2000; 47: 1001-6.

65. Sperduto PW, Kased N, Roberge D, Xu Z, Shanley R, Luo X, Sneed PK, Chao ST, Weil RJ, Suh J, Bhatt A, Jensen AW, Brown PD, et al. Summary report on the graded prognostic assessment: an accurate and facile diagnosisspecific tool to estimate survival for patients with brain metastases. J Clin Oncol. 2012; 30: 419-25. doi: 10.1200/ JCO.2011.38.0527.

66. Barnholtzsloan JS, Yu C, Sloan AE, Vengoechea J, Wang M, Dignam JJ, Vogelbaum MA, Sperduto PW, Mehta MP, Machtay M. A nomogram for individualized estimation of survival among patients with brain metastasis. Neurooncology. 2012; 14: 910-8.

67. Raizer JJ, Abrey LE. (2007). Brain Metastases: Springer US).

68. Drevelegas A. (2011). Imaging of Brain Tumors with Histological Correlations: Springer).

69. Braverman AS. Brain Metastases - Brain Metastases from Primary Tumors - Chapter 1. Brain Metastases from Primary Tumors. 2014: 3-10.

70. Seute T, Leffers P, ten Velde GP, Twijnstra A. Detection of brain metastases from small cell lung cancer: consequences of changing imaging techniques (CT versus MRI). Cancer. 2008; 112: 1827-34. doi: 10.1002/cncr.23361.

71. Jr BR, Cha S. Imaging diagnosis of brain metastasis. Progress in Neurological Surgery. 2012; 25: 55-73.

72. Soffietti R, Cornu P, Delattre JY, Grant R, Graus F, Grisold W, Heimans J, Hildebrand J, Hoskin P, Kalljo M, Krauseneck P, Marosi C, Siegal T, et al. EFNS Guidelines on diagnosis and treatment of brain metastases: report of an EFNS Task Force. Eur J Neurol. 2006; 13: 674-81. doi: 10.1111/j.1468-1331.2006.01506.x.

73. Fink KR, Fink JR. Imaging of brain metastases. Surg Neurol Int. 2013; 4: S209-19. doi: 10.4103/2152-7806.111298.

74. Bertolini F, Spallanzani A, Fontana A, Depenni R, Luppi G. Brain metastases: an overview. Cns Oncology. 2015; 4: 
$37-46$.

75. Network NCC. NCCN Clinical Practice Guidelines in Oncology: Central Nervous System Cancers. V.1.2016. https://wwwnccnorg/store/login/ loginaspx?ReturnURL=https://wwwnccnorg/professionals/ physician_gls/pdf/cnspdf. Accessed June 27, 2013.

76. Lin X, DeAngelis LM. Treatment of Brain Metastases. J Clin Oncol. 2015; 33: 3475-84 . doi: 10.1200/ JCO.2015.60.9503.

77. Brastianos PK, Curry WT, Oh KS. Clinical discussion and review of the management of brain metastases. Journal of the National Comprehensive Cancer Network Jnccn. 2013; 11: 1153-64.

78. Gorantla V, Kirkwood JM, Tawbi HA. Melanoma brain metastases: an unmet challenge in the era of active therapy. Curr Oncol Rep. 2013; 15: 483-91. doi: 10.1007/s11912013-0335-3.

79. Mulvenna $\mathrm{P}$, Nankivell $\mathrm{M}$, Barton $\mathrm{R}$, Faivre-Finn $\mathrm{C}$, Wilson P, McColl E, Moore B, Brisbane I, Ardron D, Holt T, Morgan S, Lee C, Waite K, et al. Dexamethasone and supportive care with or without whole brain radiotherapy in treating patients with non-small cell lung cancer with brain metastases unsuitable for resection or stereotactic radiotherapy (QUARTZ): results from a phase 3, noninferiority, randomised trial. The Lancet. 2016; 388: 2004 14. doi: 10.1016/s0140-6736(16)30825-x.

80. Bartsch R, Berghoff AS, Preusser M. Optimal management of brain metastases from breast cancer. Issues and considerations. CNS Drugs. 2013; 27: 121-34. doi: 10.1007/ s40263-012-0024-z.

81. Lukas RV, Gabikian P, Garza M, Chmura SJ. Treatment of brain metastases. Oncology. 2014; 87: 321-9. doi: $10.1159 / 000362389$.

82. Kenchappa RS, Tran N, Rao NG, Smalley KS, Gibney GT, Sondak VK, Forsyth PA. Novel treatments for melanoma brain metastases. Cancer Control Journal of the Moffitt Cancer Center. 2013; 20: 298-306.

83. Rades D, Schild SE. Do patients with a limited number of brain metastases need whole-brain radiotherapy in addition to radiosurgery? Strahlenther Onkol. 2012; 188: 702-6. doi: 10.1007/s00066-012-0093-4.

84. Nieder C, Grosu AL, Gaspar LE. Stereotactic radiosurgery (SRS) for brain metastases: a systematic review. Radiation Oncology. 2013; 9: 345-6.

85. Hiraoka A, Horiike N, Koizumi Y, Tazuya N, Ichiryu M, Nakahara H, Ochi H, Tanabe A, Doi H, Kodama A, Hasebe A, Ichikawa S, Miyamoto Y, et al. Brain Metastasis from Hepatocellular Carcinoma Treated with a CyberKnife. Internal Medicine. 2008; 47: 1993-6. doi: 10.2169/ internalmedicine.47.1373.

86. Han JH, Kim DG, Chung HT, Paek SH, Park CK, Kim CY, Kim YH, Jung HW. Stereotactic radiosurgery for brain metastases from hepatocellular carcinoma. J Neurooncol. 2013; 115: 45-51. doi: 10.1007/s11060-013-1192-5.
87. Dieterich S, Gibbs IC. The CyberKnife in Clinical Use: Current Roles, Future Expectations. Frontiers of Radiation Therapy \& Oncology. 2011; 43: 181-94.

88. Sio TT, Jang S, Lee SW, Curran B, Pyakuryal AP, Sternick ES. Comparing gamma knife and cyberknife in patients with brain metastases. Journal of Applied Clinical Medical Physics. 2013; 15: 14-26.

89. Wowra B, Muacevic A, Tonn JC. CyberKnife Radiosurgery for Brain Metastases. Progress in Neurological Surgery. 2012; 25: 201-9.

90. Tamari K. Treatment outcomes using CyberKnife for brain metastases from lung cancer. Journal of Radiation Research. 2014; 56: 151-8.

91. Yang G, Wang Y, Wang Y, Lin S, Sun D. CyberKnife therapy of 24 multiple brain metastases from lung cancer: A case report. Oncol Lett. 2013; 6: 534-6. doi: 10.3892/ ol.2013.1383.

92. Thomas MB, O'Beirne JP, Furuse J, Chan AT, AbouAlfa G, Johnson P. Systemic therapy for hepatocellular carcinoma: cytotoxic chemotherapy, targeted therapy and immunotherapy. Ann Surg Oncol. 2008; 15: 1008-14. doi: 10.1245/s10434-007-9705-0.

93. Cox J, Weinman S. Mechanisms of doxorubicin resistance in hepatocellular carcinoma. Hepatic Oncology. 2016; 3: 57-9.

94. Zeng YD, Liao H, Qin T, Zhang L, Wei WD, Liang JZ, Xu F, Dinglin XX, Ma SX, Chen LK. Blood-brain barrier permeability of gefitinib in patients with brain metastases from non-small-cell lung cancer before and during whole brain radiation therapy. Oncotarget. 2015; 6: 8366-76. doi: 10.18632/oncotarget.3187.

95. Lutterbach J, Bartelt S, Stancu E, Guttenberger R. Patients with brain metastases: hope for recursive partitioning analysis (RPA) class 3. Radiotherapy \& Oncology. 2002; 63: 339-45.

96. Mulvenna PM. The Management of Brain Metastases in Patients with Non-small Cell Lung Cancer,Äîis it Time to go Back to the Drawing Board? Clinical Oncology. 2010; 22: 365-73.

97. Batchelor TT, Byrne TN. Supportive Care of Brain Tumor Patients. Hematology/oncology Clinics of North America. 2006; 20: 1337-61.

98. Ryken TC, Mcdermott M, Robinson PD, Ammirati M, Andrews DW, Asher AL, Burri SH, Cobbs CS, Gaspar LE, Kondziolka D. The role of steroids in the management of brain metastases: a systematic review and evidence-based clinical practice guideline. Journal of neuro-oncology. 2010; 96: 103-14.

99. Glantz MJ, Cole BF, Forsyth PA, Recht LD, Wen PY, Chamberlain MC, Grossman SA, Cairncross JG. Practice parameter: anticonvulsant prophylaxis in patients with newly diagnosed brain tumors. Report of the Quality Standards Subcommittee of the American Academy of Neurology. Neurology. 2000; 54: 1886-93. 
100. Elewa H, Elrefai R, Barnes GD. Cancer-Associated Venous Thromboembolism. Curr Treat Options Cardiovasc Med. 2016; 18: 23. doi: 10.1007/s11936-016-0445-y.

101. Alvarado G, Noor R, Bassett R, Papadopoulos NE, Kim KB, Hwu WJ, Bedikian A, Patel S, Hwu P, Davies MA. Risk of intracranial hemorrhage with anticoagulation therapy in melanoma patients with brain metastases. Melanoma Res. 2012; 22: 310-5. doi: 10.1097/CMR.0b013e328353efd8.

102. Moriguchi M, Umemura A, Itoh Y. Current status and future prospects of chemotherapy for advanced hepatocellular carcinoma. Clin J Gastroenterol. 2016; 9: 184-90. doi: 10.1007/s12328-016-0670-7.

103. Zhang L, Li G. Comment on "combination treatment including targeted therapy for advanced hepatocellular carcinoma". 2016.

104. Llovet JM, Ricci S, Mazzaferro V, Hilgard P, Gane E, Blanc JF, de Oliveira AC, Santoro A, Raoul JL, Forner A, Schwartz M, Porta C, Zeuzem S, et al. Sorafenib in Advanced Hepatocellular Carcinoma. New England Journal of Medicine. 2008; 359: 378-90.

105. Kato H, Yoshida H, Taniguch H, Nomura R, Sato K, Suzuki I, Nakata R. Cyberknife treatment for advanced or terminal stage hepatocellular carcinoma. World J Gastroenterol. 2015; 21: 13101-12. doi: 10.3748/wjg.v21.i46.13101.

106. Llovet JM, Villanueva A, Lachenmayer A, Finn RS. Advances in targeted therapies for hepatocellular carcinoma in the genomic era. Nat Rev Clin Oncol. 2015; 12: 408-24. doi: 10.1038/nrclinonc.2015.103.

107 Tannock IF, Hickman JA. Limits to Personalized Cancer Medicine. New England Journal of Medicine. 2016; 375.

108. Ohri N, Kaubisch A, Garg M, Guha C. Targeted Therapy for Hepatocellular Carcinoma. Seminars in Radiation Oncology. 2016; 26: 338-43.

109. Hammoud GM, Ibdah JA. Are we getting closer to understanding intratumor heterogeneity in hepatocellular carcinoma? Hepatobiliary Surgery \& Nutrition. 2016; 5: 188-90.

110. Hong YP, Li ZD, Prasoon P, Zhang Q. Immunotherapy for hepatocellular carcinoma: From basic research to clinical use. World J Hepatol. 2015; 7: 980-92. doi: 10.4254/wjh. v7.i7.980.

111. Farkona S, Diamandis EP, Blasutig IM. Cancer immunotherapy: the beginning of the end of cancer? BMC Med. 2016; 14: 73. doi: 10.1186/s12916-016-0623-5.

112. Verdegaal EM. Adoptive cell therapy: a highly successful individualized therapy for melanoma with great potential for other malignancies. Curr Opin Immunol. 2016; 39: 90-5. doi: 10.1016/j.coi.2016.01.004.

113. Rosenberg SA, Restifo NP. Adoptive cell transfer as personalized immunotherapy for human cancer. Science. 2015; 348: 62-8.

114. Hong JJ, Rosenberg SA, Dudley ME, Yang JC, White DE, Butman JA, Sherry RM. Successful treatment of melanoma brain metastases with adoptive cell therapy. Clin Cancer
Res. 2010; 16: 4892-8. doi: 10.1158/1078-0432.CCR-101507.

115. Liu D, Staveley-O'Carroll KF, Li G. Immune-based Therapy Clinical Trials in Hepatocellular Carcinoma. J Clin Cell Immunol. 2015; 6. doi: 10.4172/2155-9899.1000376.

116. Jiang SS, Tang Y, Zhang YJ, Weng DS, Zhou ZG, Pan K, Pan QZ, Wang QJ, Liu Q, He J. A phase I clinical trial utilizing autologous tumor-infiltrating lymphocytes in patients with primary hepatocellular carcinoma. Oncotarget. 2015; 6: 41339-49. doi: 10.18632/oncotarget.5463.

117. Rosenberg SA, Yang JC, Sherry RM, Kammula US, Hughes MS, Phan GQ, Citrin DE, Restifo NP, Robbins PF, Wunderlich JR, Morton KE, Laurencot CM, Steinberg $\mathrm{SM}$, et al. Durable complete responses in heavily pretreated patients with metastatic melanoma using T-cell transfer immunotherapy. Clin Cancer Res. 2011; 17: 4550-7. doi: 10.1158/1078-0432.CCR-11-0116.

118. Prins RM, Vo DD, Khan-Farooqi H, Yang MY, Soto H, Economou JS, Liau LM, Ribas A. NK and CD4 cells collaborate to protect against melanoma tumor formation in the brain. Journal of Immunology. 2006; 177: 8448-55.

119. Wilson EH, Weninger W, Hunter CA. Trafficking of immune cells in the central nervous system. Journal of Clinical Investigation. 2010; 120: 1368-79.

120. Tagliamonte M, Petrizzo A, Tornesello ML, Ciliberto G, Buonaguro FM, Buonaguro L. Combinatorial immunotherapy strategies for hepatocellular carcinoma. Curr Opin Immunol. 2016; 39: 103-13. doi: 10.1016/j. coi.2016.01.005.

121. Hato T, Goyal L, Greten TF, Duda DG, Zhu AX. Immune checkpoint blockade in hepatocellular carcinoma: current progress and future directions. Hepatology. 2014; 60: 177682. doi: 10.1002/hep. 27246 .

122. Sangro B, Gomez-Martin C, de la Mata M, Inarrairaegui M, Garralda E, Barrera P, Riezu-Boj JI, Larrea E, Alfaro C, Sarobe P, Lasarte JJ, Perez-Gracia JL, Melero I, et al. A clinical trial of CTLA-4 blockade with tremelimumab in patients with hepatocellular carcinoma and chronic hepatitis C. J Hepatol. 2013; 59: 81-8. doi: 10.1016/j. jhep.2013.02.022.

123. Elkhoueiry AB, Sangro B, Yau TC, Crocenzi TS, Welling TH, Yeo W, Chopra A, Anderson J, Dela Cruz CM, Lang L. Phase I/II safety and antitumor activity of nivolumab (nivo) in patients (pts) with advanced hepatocellular carcinoma (HCC): Interim analysis of the CheckMate-040 dose escalation study. 2016.

124. Sangro B, Melero I, Yau TC, Hsu C, Kudo M, Crocenzi TS, Kim TY, Choo SP, Trojan J, Meyer T. Safety and antitumor activity of nivolumab (nivo) in patients (pts) with advanced hepatocellular carcinoma (HCC): Interim analysis of doseexpansion cohorts from the phase 1/2 CheckMate-040 study. 2016.

125. Margolin K, Ernstoff MS, Hamid O, Lawrence D, McDermott D, Puzanov I, Wolchok JD, Clark JI, Sznol 
M, Logan TF, Richards J, Michener T, Balogh A, et al. Ipilimumab in patients with melanoma and brain metastases: an open-label, phase 2 trial. The Lancet Oncology. 2012; 13: 459-65. doi: 10.1016/s1470-2045(12)70090-6.

126. Kluger HM, Goldberg SB, Sznol M, Tsiouris J, Vortmeyer A, Jilaveanu L, Ralabate AL, Rivera AL, Burke MM, Hegbe UP. Safety and activity of pembrolizumab in melanoma patients with untreated brain metastases. 2015.

127. Goldberg SB, Gettinger SN, Mahajan A, Herbst RS, Chiang AC, Tsiouris AJ, Vortmeyer A, Jilaveanu L, Speaker S, Madura M. Activity and safety of pembrolizumab in patients with metastatic non-small cell lung cancer with untreated brain metastases. 2015.

128. Ahmed KA, Stallworth DG, Kim Y, Johnstone PA, Harrison LB, Caudell JJ, Yu HH, Etame AB, Weber JS, Gibney GT. Clinical outcomes of melanoma brain metastases treated with stereotactic radiation and anti-PD-1 therapy. Ann Oncol. 2016; 27: 434-41. doi: 10.1093/annonc/mdv622.

129. Goldberg SB, Gettinger SN, Mahajan A, Chiang AC, Herbst RS, Sznol M, Tsiouris AJ, Cohen J, Vortmeyer A, Jilaveanu L. Pembrolizumab for patients with melanoma or non-small-cell lung cancer and untreated brain metastases: early analysis of a non-randomised, open-label, phase 2 trial. Lancet Oncology. 2016; 17: 976-83.

130. Metro G, Lunardi G, Bennati C, Chiarini P, Sperduti I, Ricciuti B, Marcomigni L, Costa C, Crino L, Floridi P. Alectinib's activity against CNS metastases from ALK -positive non-small cell lung cancer: a single institution case series. Journal of Neuro-Oncology. 2016; 129: 1-7.

131. Yang CH, Ou SHI, De Petris L, Gadgeel SM, Gandhi L, Kim DW, Barlesi F, Govindan R, Dingemans AMC, Crino L. Efficacy and safety of alectinib in ALK+ non-small-cell lung cancer (NSCLC): Pooled data from two pivotal phase II studies (NP28673 and NP28761). 2016.

132. Stang K, Silva S, Block AM, Welsh JS. The integration of radiation therapy and immunotherapy in melanoma management. Journal of Radiation Oncology. 2016: 1-12. 